\title{
MEMBACA MATERIALITAS ILMU BERDASARKAN FILSAFAT TEKNOLOGI DON IHDE
}

\author{
Budi HaRTANTO*
}

\begin{abstract}
Abstrak: Artikel ini membahas relevansi teknologi dalam diskursus filsafat ilmu. Saya merujuk pada fenomenologi instrumentasi Don Ihde yang berfokus pada pemikiran tentang intensionalitas instrumental. Instrumen bersifat non-netral yang menentukan bagaimana kita menggapai pengetahuan. Menurut Ihde, ilmu menubuh dengan teknologi. Ia berargumen filsafat ilmu mesti mempertimbangkan pentingnya praksis dan instrumentasi alih-alih teoritisasi. Selain itu akan dibahas problem persepsi dalam ilmu dengan berpijak pada pemikiran Ihde tentang hermeneutika material. Dengan hermeneutika ini, kita menyadari bahwa materialitas ilmu bersifat reduktif terhadap kompleksitas dunia inderawi dan bahwa pengetahuan meluas melampaui daya persepsi. Dari problem persepsi dalam ilmu, saya akan menjelaskan hermeneutika instrumen keilmuan sebagai moda pembacaan materialitas ilmu yang meliputi konstruksi teknologis instrumen. Instrumen dijelaskan sebagai bagian integral dari fakta dalam ilmu. Pada bagian akhir akan dibahas realisme fenomenologis ruangsiber dimana instrumen terintegrasi ke dalam ruangsiber.
\end{abstract}

Kata-kata Kunci: Pascafenomenologi, intensionalitas, teknologi, mediasi instrumental, hermeneutika, ruangsiber.

Abstract: This article elucidates the relevance of technology in the discourse of philosophy of science. I refer to Don Ihde's phenomenology of instrumentation that focuses on the idea of instrumental intentionalities. Instrument is defined as non-neutral that determines how we obtain knowledge. According to Ihde, philosophy of science must consider the importance of praxis and instrumentation instead of theoritization. In

* Budi Hartanto, The Society for Philosophy and Technology . Address: Philosophy Documentation Center, PO Box 7147, Charlottesville VA 22906-714. Email: filstek3@yahoo.com. 
addition, I will also address the problem of perception in science, realizing that reality tends to be reduced in the materiality of scientific knowledge and that our knowledge always expands beyond sense-perception. From this problem of perception, I elaborate a hermeneutics of scientific instrument based on Ihde's material hermeneutics. In this hermeneutics, the materiality of scientific knowledge is read through technological construction instrument. Here instrument is categorized as an integral part of scientific fact. I will conclude by describing a phenomenological realism of cyberspace where instrument is integrated into cyberspace.

Keywords: Postphenomenology, intentionality, technology, instrumental mediation, hermeneutics, cyberspace.

\section{PENDAHULUAN}

Kajian tentang teknologi dalam praksis keilmuan berawal dari filsafat Martin Heidegger. Teknologi dijelaskan olehnya tidak sekadar untuk menggapai tujuan, kemudahan, dan menyelesaikan persoalan dalam hidup. Ia merujuk pada kata techne yang berasal dari Yunani kuno yang bermakna lebih dari skill atau kemampuan teknis. Teknologi dalam arti techne memiliki kesamaan dengan kreatifitas dalam membuat sesuatu yang baru. Inilah yang mendasari pemikiran Heidegger tentang esensi teknologi dalam arti enframing yang merupakan penyingkapan realitas sebagai moda kebenaran.

Teknologi menurut Heidegger menjadi rasional tidak melalui penerapan sebuah teori atau lebih spesifik mathematical physical science. ${ }^{1}$ Keterciptaan teknologi atau lebih khusus mesin adalah berdasarkan eksperimentasi yang merupakan suatu praksis. Dari pandangan Heidegger ini dapat kita ketahui bagaimana pada awalnya teknologi tidak dikategorikan sebagai ilmu pengetahuan. Penggunaan instrumen dalam ilmu, misalnya, menempatkan teknologi secara ontologis sebagai standing reserve. ${ }^{2}$ Sebagai standing reserve, teknologilah yang menurutnya menjadi

1 Martin Heidegger, The Question Concerning Technology and Other Essays (New York: Harper and Row, 1977), p. 116.

2 Don Ihde, Technics and Praxis (Holland and Boston: D. Riedle Publishing Company, 1979), pp. 110-111. 
prakondisi dari ilmu. Dari sini Heidegger kemudian membalikkan pemikiran tentang ilmu yang menjadi prakondisi dari teknologi.

Keutamaan teknologi sebagaimana dirumuskan Heidegger dielaborasi oleh Don Ihde. Ihde dikenal sebagai filsuf yang memperkenalkan fenomenologi ke dunia filsafat di Amerika. Ia banyak menulis tematema filsafat sains, teknologi dan hermeneutika. Ihde menuliskan filsafat teknologinya dari perspektif fenomenologi. Filsafat teknologi Ihde memiliki kekhasan yang membahas teknologi dalam kapasitasnya untuk menggapai pengetahuan. Teknologi direfleksikan tidak hanya pada makna instrumentalnya untuk mengatasi persoalan praktis dalam kehidupan sebagaimana para filsuf teknologi lainnya. Ia mengategorikan filsafat teknologinya ke dalam apa yang kemudian dikenal dengan pascafenomenologi. Pascafenomenologi berawal dari peralihan konsep subjek Husserlian yang berpusat pada ego transendental menjadi tubuh eksistensial. Menurut Ihde, tak ada ego transendental atau subjek yang bersifat metafisis sebagaimana tersebut dalam filsafat Husserl. Pemikiran ini berpijak dari fenomenologi persepsi Maurice Merleau-Ponty dan terutama argumen Ihde tentang ketidakmungkinan subjek Cartesian melalui metafora camera obscura. ${ }^{3}$ Menurut Ihde,

This trajectory was already partially postmodern in that the modern or "Cartesian" subject was replaced with an existential "lived body," a kind of organism/environment model of interpretation which reembodied the human within a world or environment. The entire apparatus of "sensation," "sense data," even Husserlian "hyletic data," but also inferred material being, the "res extensa," disappears

3 Camera obscura adalah ruang gelap yang di dalamnya terdapat proyeksi cahaya yang me-refleksikan dunia luar ruang gelap. Ihde menanggapi teori pengetahuan René Descartes tentang eksistensi subjek tak tercerap melalui metafora camera obscura. Menurutnya ada kerancuan dalam analogi camera obscura yang digunakan oleh Descartes yang menganalogikan lubang ruang gelap yang memproyeksikan cahaya sebagai pikiran. Ihde mengkritik bahwa Descartes menafikan eksistensi ruang eksternal yang mengondisikan subjek yang mencerap dan proyeksi cahaya dalam ruang gelap. Don Ihde, Bodies in Technology (Minneapolis: University of Minnesota Press, 2002), p. 71. 
and is replaced by a more Merleau-Pontian "fleshly" interactive relativity. The "body" remains one strong thematic emphasis in the newer "theory" approaches, particularly within contemporary feminist discourse. ${ }^{4}$

Pembahasan utama pascafenomenologi selain kesadaran menubuh adalah mediasi teknologis. Intensionalitas dijelaskan tidak hanya menyangkut kapasitas motorik tubuh dengan segala potensi inderawinya, melainkan juga dalam relasi dengan instrumen. Dapat dikatakan semua ilmu dapat dilihat sebagai pascafenomenologi. Mengenai mediasi teknologis dalam ilmu secara lebih khusus dieksplorasi oleh Ihde dalam fenomenologi instrumentasi. Dalam tulisan ini saya membahas filsafat teknologi Ihde yang meliputi tema fenomenologi instrumentasi, hermeneutika material dan realisme fenomenologis. Berdasarkan tema-tema tersebut, saya akan menjelaskan hermeneutika instrumen, yaitu tentang konstruksi dan mediasi teknologis dalam ilmu dan realisme instrumental ruangsiber di mana instrumen terintegrasi dengan teknologi informasi.

\section{INTENSIONALITAS DAN MEDIASI INSTRUMENTAL ILMU PENGETAHUAN}

Filsafat teknologi Don Ihde berpijak pada fenomenologi Edmund Husserl, Maurice Merleau-Ponty dan Martin Heidegger. Para filsuf tersebut memiliki kesamaan membahas fenomenologi dalam filsafat ilmu. Refleksi eksistensial tentang keberadaan manusia di dunia yang merupakan ciri dari pengetahuan fenomenologis menjadi basis dari praksis keilmuan. Ilmu selalu berdasar pada dunia pengalaman sebagai sebuah ontologi yang merupakan struktur terberi dari eksistensi.

Husserl mengawali kritik terhadap sains modern dalam perspektif filsafat fenomenologis. Ia menjelaskan tentang pentingnya dunia prakeilmuan (prescientific world) yang mensyaratkan pemahaman akan keutuhan kualitas dunia inderawi. Hal ini bermula dari tanggapannya

4 Don Ihde, Postphenomenology: Essays in the Postmodern Context (Evanston, IL: Northwestern University Press, 1993), p. 3. 
terhadap Galileo Galilei yang mengutamakan objektivitas yang bersifat matematis. Husserl mengkritisi sains pasca Galileo yang lebih menggunakan penalaran geometris yang bersifat abstrak-ideal. ${ }^{5}$ Mengenai hal ini kita juga bisa lihat penjelasannya tentang pemikiran David Hume yang menyatakan objektivitas matematis yang bersifat abstrak-ideal dan bahkan dunia yang kita persepsikan adalah fiksi. Hume berpijak pada pemikiran tentang realitas yang dipahami sebagai relasi dan asosiasi idea-idea yang selalu berubah atau tidak selalu pada suatu posisi tertentu. ${ }^{6}$

Filsafat Husserl menjadi sumber utama untuk memahami konsep intensionalitas yang merupakan basis dari metode analisa fenomenologis. Intensionalitas didefinisikan sebagai struktur korelasi ego transendental yang tertuju pada dunia pengalaman. Dalam praksis keilmuan, intensionalitas tidak berhenti pada fenomena yang ingin diketahui, melainkan kembali ke dalam kesadaran yang mengetahui. Kesadaran yang tertuju dan tersituasikan pada fenomena tertentu ini diistilahkan oleh Husserl dengan noemata. Intensionalitas ini tidak bersifat pasif, ego transendental memahami dunia dari perspektif-perspektif tertentu sehingga membentuk variasi-variasi fenomenologis. Pengetahuan dalam fenomenologi selalu bersifat relatif. Meski demikian, intensionalitas ini masih dalam batasbatas ego transendental sebagai entitas metafisis yang tak tercerap keberadaannya.

Intensionalitas kemudian menjadi lebih membumi melalui fenomenologi persepsi Merleau-Ponty. Ego transendental dalam filsafat Husserl tergantikan dengan tubuh (corps vecu). Merleau-Ponty mendekonstruksi subjek Husserlian yang bersifat transendental yang tidak bisa dicerap keberadaannya. Tubuh memahami dunia karena ia merupakan bagian darinya. Ia mengistilahkan tubuh yang memahami dunia dengan flesh

5 Don Ihde, Technology and the Lifeworld: From Garden to Earth (Bloomington: Indiana University Press, 1990), p. 35.

6 Edmund Husserl, The Crisis of European Science and Trancendental Phenomenology (Evanston, IL: Northwestern University Press, 1970), p. 86. 
yang adalah bagian dari flesh yang lebih luas. ${ }^{7}$ Tubuh manusia sebagai kesatuan organis eksistensi memahami dunia karena ia memiliki esensi yang sama dengan tubuh dunia. Kesamaan esensinya ini tentunya adalah sebagai suatu materi yang dapat dipersepsikan.

Persepsi yang mengonstruksi pengetahuan dalam fenomenologi Merleau-Ponty tersituasikan oleh aktivitas intensional motorik (body-inaction). ${ }^{8}$ Persepsi kita terhadap dunia tidak bersifat fixed seperti halnya abstraksi yang bersifat representasional Cartesian. Persepsi ini bukanlah sesuatu yang menggejala dalam pikiran sebagaimana dalam filsafat Descartes, tapi tidak lantas ia murni bersifat materialistis. Persepsi inderawi selalu mengandaikan cara pandang dunia sebagai sebuah gestalt. Pengalaman gestalt ini terbentuk berdasarkan investigasi fenomenologis. Inilah menurut Merleau-Ponty yang menjadi dasar semua ilmu, ia tidak dapat tercerabut dari dunia pengalaman. ${ }^{9}$

Intensionalitas dalam diskursus fenomenologi tidak hanya dalam kapasitas persepsi kebertubuhan. Dalam perspektif filsafat Heidegger, intensionalitas adalah suatu tindakan yang merupakan pengetahuan praksis. Heidegger berbeda pandangan dengan Husserl dan MerleauPonty mengenai konsep intensionalitas. Intensionalitas bukanlah persepsi inderawi yang tertuju pada dunia mengingat manusia sudah selalu berada dalam dunia (being-in-the-world), melainkan suatu praksis yang meliputi kualitas-kualitas eksistensial yang dirasakan. ${ }^{10}$ Pengetahuan praksis ini menurut Heidegger adalah juga dalam relasi dengan teknologi. Ketika kita menggunakan instrumen tertentu, terbentuk relasi ontologis manusia-teknologi, teknologi menjadi mode of being atau istilah Heidegger ready to hand. Pengetahuan praksis dalam relasinya dengan

7 Maurice Merleau-Ponty, The Visible and the Invisible (Evanston, IL: Northwestern University Press, 1968), pp. 193, 248.

8 Don Ihde, Technology and the Lifeworld: From Garden to Earth, p. 38.

9 Maurice Merleau-Ponty, Phenomenology, Language and Sociology: Selected Essays of Maurice Merleau-Ponty (Heineman Educational, 1974), p. 197.

10 Don Ihde, Technics and Praxis, p. 117. 
teknologi ini oleh Heidegger dijelaskan dalam tataran eksistensial alihalih tataran kognitif.

Relevansi fenomenologi dalam filsafat ilmu seperti dalam filsafat Husserl, Heidegger, dan Merleau-Ponty menjadi kerangka utama filsafat teknologi Ihde. Ihde mengeksplorasi fenomenologi tentang instrumen yang menjadi ekstensi kapasitas kebertubuhan atau yang ia istilahkan dengan fenomenologi instrumentasi. Fenomenologi ini terutama menjelaskan bagaimana persepsi ditransformasikan yang kemudian mengonstruksi intensionalitas berdasarkan relasi-relasi instrumental. Dalam relasi manusia-instrumen, menurut Ihde, ada dua bentuk relasi yang penting untuk diketahui dalam diskursus filsafat ilmu, yakni relasi kemenubuhan dan relasi hermeneutis. Dua bentuk relasi ini menyatakan bahwa antara manusia dan dunia yang tak terjangkau secara inderawi terdapat "mediator."11

Manusia $\longrightarrow$ Internet (Mediator) $\longrightarrow$ Dunia

Dalam relasi kemenubuhan, tubuh dan instrumen menjadi kesatuan relasional fenomenologis. Ihde mengacu Heidegger mengenai transparansi relasi manusia-instrumen. Ketika menggunakan instrumen, kesadaran tertuju pada objeknya bukan instrumen yang digunakan. Menggergaji kayu, gergaji tidak disadari keberadaannya secara eksistensial, karena kesadaran tertuju pada kayu. Manusia dan instrumen mewujud sebagai kesatuan relasional. Ia menjadi ekstensi dari tubuh dalam relasinya dengan dunia pengalaman. Tentu ketercerabutan pengalaman mediasi instrumental ini tidak membuatnya tak bermakna. Kesatuan relasional menjadikannya sebagai mediator dalam relasi kemenubuhan.

Kesatuan relasional manusia-instrumen menjadi syarat pencapaian pengetahuan. Keseluruhan kualitas dunia inderawi tereduksi pada kualitas tertentu, pada saat yang sama teramplifikasi. Mikroskop memediasikan dunia yang tak dapat dipersepsi dan mereduksinya sebatas

11 Don Ihde, Technics and Praxis, pp. 28-33. 
citra dua dimensi di permukaan lensa atau sebatas visual. Dalam relasi kemenubuhan, amplifikasi tidak selalu menghadirkan pengetahuan sebagaimana dalam dunia keseharian. Instrumen mengamplifikasi kualitas inderawi tertentu sehingga yang ditampilkannya tak terpahami secara langsung. Seiring dengan berkembangnya teknologi, seperti mikroskop elektron dengan kapasitas pembesaran lebih jauh dari mikroskop cahaya, dunia yang dimediasikannya semakin berjarak sehingga terbentuk gap dengan dunia pengalaman keseharian. Dunia termediasi relasi kemenubuhan sampai pada fase ketika ia memerlukan pembacaan.

Dunia inderawi dipersepsikan dalam relasi kemenubuhan melalui mediator yang terkonstruksi secara teknologis. Mediator tentu tidak begitu saja memediasikan pengetahuan. Mediasi teknologis ini perspektif filsafat Heidegger dikategorikan sebagai sebuah poiesis yang merupakan makna lebih luas dari teknologi dalam arti techne. Nilai poiesis dari teknologi dalam konteks mediasi instrumental ilmu adalah penyingkapan realitas melalui konstruksi teknologis. Instrumen menjadi ekstensi kapasitas kebertubuhan, atau secara lebih khusus dalam praksis keilmuan, ia menjadi ekstensi dari persepsi inderawi. Dunia inderawi yang sebelumnya tidak diketahui mewujud dalam bentuk variasi fenomenologis instrumental.

Bila dalam relasi kemenubuhan instrumen dan tubuh tak berjarak, dalam relasi hermeneutis ia berjarak secara relasional fenomenologis. Thermometer memediasikan kadar suhu yang tak dapat dipersepsi. Tubuh tidak merasakan secara langsung kadar suhu, melainkan membacanya dengan mediasi thermometer. Pembacaan dunia melalui thermometer menyatakan amplifikasi dan reduksi bersifat perseptual hermeneutis, suhu tidak dipersepsikan secara inderawi oleh tubuh sebagaimana relasi kemenubuhan. Instrumen memediasikan suhu dan zatzat tertentu yang tak dapat dipersepsi dalam bentuk teks.

Intensionalitas dalam mediasi instrumental ilmu dalam relasi hermeneutis tidak tertuju secara langsung pada dunia. Kita mengetahui fenomena tanpa mempersepsikan kualitas kebertubuhannya sebagai- 
mana dalam relasi kemenubuhan. Instrumen-instrumen sains kontemporer seperti kita ketahui memiliki moda mediasi pengetahuan melalui pembacaan. Dengan relasi hermeneutis, pengalaman kebertubuhan dalam menggapai ilmu tidak menjadi keutamaan. Mediasi teknologis memungkinkan kita membacanya dan mempersepsikannya. Berbeda dengan relasi kemenubuhan, meski sama-sama termediasi oleh instrumen, fenomena tetap mewujud secara isomorfis dengan fenomena yang dipersepsikan tanpa instrumen. Dalam relasi hermeneutis, fenomena tereduksi dalam bentuk teks dan teramplifikasi sebagai referensi fenomena sesungguhnya.

Fenomenologi persepsi Merleau-Ponty dapat menjadi acuan untuk memahami moda pengetahuan dalam relasi hermeneutis ini. MerleauPonty menyatakan bagaimana persepsi kita selalu berkembang dan terkondisikan oleh pengalaman. Bila kita melihat suatu benda dalam perspektif kebertubuhan tertentu akan muncul dalam kesadaran bagianbagian lainnya yang tidak diketahui yang dihasilkan dari pengalaman. Dalam relasi hermeneutis, persepsi mengenai fenomena yang dimediasikan instrumen adalah sama dengan persepsi yang berkembang yang merupakan basis dari semua pengetahuan. Hanya saja dalam relasi hermeneutis, persepsi termediasi oleh teks yang menjadi referensi dunia sesungguhnya, sedangkan dalam fenomenologi Merleau-Ponty, persepsi tersebut terbentuk secara kultural dan karena itu tidak bisa menghadirkan kebenaran. ${ }^{12}$

Berdasarkan relasi kemenubuhan dan hermeneutis, Ihde merumuskan lebih rinci variasi-variasi fenomenologis dimana pengetahuan diperoleh mengacu intensionalitas instrumental. Intensionalitas instrumental adalah cara bagaimana instrumen secara teknis menentukan dan mengkondisikan bentuk dan wujud materialitas pengetahuan. Intensionalitas ini dikategorikan oleh Ihde ke dalam variasi-variasi seperti

12 Maurice Merleau-Ponty, Phenomenology, Language and Sociology, p. 198.

13 Don Ihde, Technics and Praxis, pp. 34-35. 
horisontal instrumental variant dan vertical instrumental possibility. ${ }^{13}$ Dalam variasi horisontal, dunia teramplifikasi dengan bentuk yang berbeda yang mengindikasikan sebuah pengetahuan. RTI (reflectance transformational imaging) adalah teknologi terbaru fotografi komputasional dalam ilmu arkeologi yang dapat menampilkan relief gambar dan tulisan pada sebuah batu dengan lebih jelas. RTI menampilkan citra dengan cara mengambil foto relief dari berbagai perspektif dan pencahayaan. Hasil pencitraan melalui pencahayaan kamera ini datanya dimasukan ke dalam komputer sehingga dapat diproses secara matematis. Pengaturan cahaya dengan komputer menghasilkan gambar dan tulisan tanpa bayangan sebagaimana melihatnya secara langsung dan dapat dilihat dari perspektif yang berbeda-beda. ${ }^{14}$ Amplifikasi variasi horisontal menghasilkan dunia yang terkondisikan secara teknologis yang merupakan pengetahuan dalam konteks fenomenologi instrumentasi.

Instrumentasi variasi horisontal dikategorikan ke dalam relasi kemenubuhan. Dunia tetap mewujud secara isomorfis dengan dunia sesungguhnya. Namun ia tidak sama dengan teknologi optis yang secara teknis memediasikan dengan kualitas yang sama. Amplifikasi pengetahuan dalam variasi horisontal merepresentasikan dunia dengan efek tertentu. Bentuk yang dimediasikannya tetap sama, namun dengan kualitas amplifikasi pengetahuan yang berbeda. Dalam ilmu geografi, teknologi inframerah membuat kita dapat membaca lebih jelas pengetahuan tertentu yang ada di permukaan Bumi. Foto sungai dengan teknologi inframerah dari ketinggian menghasilkan citra sungai dengan kualitas pencahayaan tertentu yang membuat arah alirannya terlihat lebih jelas dibandingkan dengan foto tanpa teknologi inframerah.

Variasi lainnya menurut Ihde adalah vertical instrumental possibilty. Dalam variasi ini, dunia mewujud dalam bentuk yang sama sekali berbeda dengan dunia sesungguhnya. Dunia tereduksi dalam wujud

14 Marta Díaz-Guardamino, "Rock Art and Digital Technologies: the Application of Reflectance Transformation Imaging (RTI) and 3D Laser Scanning to the Study of Late Bronze Age Iberian Stalae," Menga: Journal of Andalusian Prehistory, Tahun 3, nomor 4 (2013): 187-203. 
teks yang kemudian dibaca dan ditransformasikan ke dalam variasi horisontal. Radio telescope memberi informasi benda-benda langit yang tak dapat dipersepsi dengan mendeteksi gelombang elektromagnetik yang dipancarkan. Materialitas benda-benda langit diketahui dalam bentuk frekuensi melalui antena yang kemudian diamplifikasi oleh receiver dan ditransformasikan oleh komputer ke dalam wujud visual. Dalam variasi vertikal, instrumen mengamplifikasi dan merepresentasikan dengan kualitas yang terkondisikan secara teknis dalam bentuk teks. Variasi vertikal merupakan relasi hermeneutis. Kita mengetahui materialitas ilmu melalui pembacaan. Instrumen memprobe dan mendekonstruksi dunia yang eksistensinya berjarak atau tidak diketahui secara inderawi.

Dari relasi-relasi dan variasi-variasi instrumental fenomenologis, dapatlah kita simpulkan tentang signifikansi fenomenologi instrumentasi dalam menggapai pengetahan. Intensionalitas-intensionalitas instrumental yang menentukan bentuk pengetahuan menjelaskan bahwa teknologi bersifat non-netral. Non-netralitas inilah yang kemudian membawa pada pemikiran tentang simetri manusia dan artefak teknologi. Namun simetri ini tetap dalam konteks relasi manusia-instrumen. Non-netralitasnya dapat dijelaskan karena ia memiliki karakter teknis yang berpengaruh terhadap bagaimana kita menggapai pengetahuan. ${ }^{15}$ Menghitung dengan abacus berbeda dengan menghitung menggunakan kalkulator atau lebih kompleks lagi dengan komputer.

Intensionalitas dan mediasi-mediasi instrumental seperti tersebut dalam pemikiran Ihde relevan untuk diketahui sebagai metode dalam filsafat ilmu. Ilmu adalah suatu praksis dan menubuh dengan teknologi. Ihde dengan pascafenomenologinya mengkritisi filsafat ilmu yang berfokus pada bagaimana pengetahuan digapai dengan metode berpikir tertentu atau membahas teori pengetahuan dalam batas-batas logika formal. Pandangan Ihde bahwa ilmu menubuh dengan teknologi merupakan suatu peralihan dari filsafat ilmu menuju filsafat teknologi.

15 Don Ihde, Technics and Praxis, pp. 41-43. 


\section{HERMENEUTIKA INSTRUMEN KEILMUAN}

Seperti telah dijelaskan dalam fenomenologi instrumentasi, amplifikasi dan magnifikasi menghasilkan variasi-variasi fenomenologis. Pengetahuan yang dihasilkan melalui instrumentasi mensyaratkan sebuah pembacaan. Pada bagian ini saya mendedah hermeneutika instrumen dengan mengacu pada problem persepsi dalam ilmu pengetahuan. Pemikiran ini dielaborasi berdasarkan filsafat Don Ihde tentang hermeneutika material.

Hermeneutika material Ihde dirumuskan dari tradisi hermeneutika fenomenologis yang menggarisbawahi intensionalitas dan pengetahuan praksis. Persepsi inderawi dan instrumentasi atau istilah Ihde mikropersepsi digunakan untuk menafsir fenomena dalam ilmu-ilmu sosial dan ilmuilmu alam. Ihde mengkritisi tradisi hermeneutika yang berfokus pada kajian yang bersifat linguistik yang bermula dari Wilhelm Dilthey dan Friedrich Schleiermacher. ${ }^{16}$ Meski dalam perkembangannya ia menjadi argumen untuk menjelaskan eksistensi manusia atau sebuah ontologi seperti dalam hermeneutika Heidegger dan Paul Ricouer ia tetap dalam batas-batas logosentrisme.

Menurut Ihde, ilmu pada dasarnya adalah sebuah hermeneutika. Ilmu adalah kegiatan menafsir secara perseptual fenomena yang dalam arti tertentu berbicara atau memberi makna seperti halnya teks. Dalam ilmu sejarah, misalnya, materialitas benda bersejarah menjadi sumber hermeneutis untuk memahami suatu peristiwa. Peristiwa dalam sejarah dapat ditafsirkan dengan pembacaan suatu benda. Benda bersejarah memendarkan makna seperti halnya sebuah teks. Seperti juga ilmu-ilmu lainnya dalam memperoleh pengetahuan selalu mengandaikan pembacaan materialitasnya. Materialitas menjadi tolok ukur validitas sebuah pengetahuan atau menjadi pijakan untuk menjelaskan suatu teori dalam ilmu.

16 Don Ihde, Postphenomenology and Technoscience: Peking University Lecture, SUNY Series of the Philosophy of the Social Sciences (New York: State University of New York Press, 2009), pp. 63-77. 
Materialitas yang mewujud secara partikular-reduktif dan terkondisikan oleh teknologi yang merupakan ciri hermeneutika material dan menjadi acuan dari kegiatan hermeneutis dalam ilmu. Hal ini tentunya tak lepas dari kenyataan tentang keterbatasan persepsi dan instrumentasi. Dalam menafsir fenomena dalam ilmu, pemahaman selalu bergerak melampaui dimensi materialnya dan tak bisa menjadi absolut. Karena itu hermeneutika material tetap dipahami sebagai metode. Ilmu tentu tidak hanya mengenai materialitasnya, pencapaian ilmu adalah juga dengan persepsi keilmuan yang dikategorikan oleh Ihde dengan makropersepsi atau persepsi yang bersifat kultural.

Persepsi keilmuan (atau teori) dalam hermeneutika material tidak bisa dijadikan pijakan untuk menggapai kepastian pengetahuan. Kendati demikian, tak sedikit ilmuwan menggunakan persepsi keilmuan dalam menggapai pengetahuan. Argumen tentang ini dapat kita lihat pada Albiruni, ilmuwan Muslim abad pertengahan, seorang penemu ilmu geodesi. Albiruni menggunakan matematika untuk mengukur keliling Bumi. Albiruni mengukur keliling Bumi dari puncak gunung yang berdekatan dengan laut. Ia mengukur tinggi gunung dengan rumus Pythagoras, lalu mengobservasi lintasan Matahari dan batas cakrawala. Dengan persepsi keilmuan, dalam hal ini perhitungan matematis, ia mengukur keliling Bumi dengan tanpa harus mengelilinginya. ${ }^{17}$ Hasil pengukuran ini memililki kesamaan atau mendekati hasil pengukuran dengan teknologi satelit pada masa modern.

Albiruni mengukur keliling Bumi dengan membaca fenomena visual. Dalam filsafat Ihde, yang dilakukan oleh Albiruni dapat dikategorikan sebagai hermeneutika visual yang merupakan percabangan dari hermeneutika material. ${ }^{18}$ Namun Albiruni tidak semata-mata menafsir secara

17 Seyyed Hosein Nasr. An Introduction to Islamic Cosmological Doctrines: Conceptions of Nature and Methods Used for its Study by Ikhwan Al-Shafa, Al-Biruni, and Ibn Sina. (The Pitman Press, Great Britain, 1978), pp. 128-131.

18 Eratosthenes ilmuwan Yunani kuno lebih dulu mengukur keliling Bumi dengan metode yang berbeda dari Albiruni. Eratosthenes mengukur jarak dan sudut bayangan di dua kota yang berbeda. Ihde mengatakan bahwa kegiatan yang 
visual, tetapi juga menggunakan ilmu ukur sudut (trigonometri). Albiruni mengetahui keliling Bumi yang melampaui kapasitas daya persepsi inderawi, namun yang diketahuinya adalah realitas abstrak dan matematis. Mengenai hal ini Albiruni berpandangan bahwa alam dan matematika adalah memang realitas yang sama. Angka-angka menurutnya dapat ditemui di alam kehidupan. Ia menganalisa bunga-bunga dan dedaunan yang menurutnya seiring dengan hukum-hukum geometri. ${ }^{19}$

Albiruni tak berbeda dengan Galileo yang melihat pentingnya matematika dalam memahami alam semesta. Alam semesta dalam filsafat ilmu Galileo menjadi rasional mestilah dari suatu penalaran geometris. Ilmu yang berorientasi pada sesuatu yang abstrak dan matematis seperti Albiruni dan Galileo seperti kita ketahui mendapat tanggapan dari Husserl. Kompleksitas dunia inderawi, menurut Husserl, tidak bisa direduksi hanya pada sesuatu yang matematis. Galileo, menurut Husserl, tidak mempertimbangkan pentingnya kualitas dunia inderawi yang bersifat kompleks yang seharusnya menjadi sumber utama pengetahuan. ${ }^{20}$

Kritik Husserl terhadap pengetahuan abstrak dan matematis ini dapat kita telaah dari perhitungan frekuensi tegangan senar piano. Perhitungan teoritis frekuensi piano tidak bisa berkorespondensi dengan tepat dengan dunia sesungguhnya. Bila kita membuat skala nada harmoni pada piano, rasio frekuensi nada selalu lebih tinggi 1 atau 2 cent. Bila frekuensi nada A $440 \mathrm{~Hz}$, nada A oktaf berikutnya menurut perhitungan seharusnya $880 \mathrm{~Hz}$, namun dalam realitasnya lebih 2 cent (I cent $=1 / 4$ putaran gelombang senar perdetik). Nada A selanjutnya jadi lebih 4 cent. Demikian seterusnya sehingga tak bisa tepat menurut rasio perhitungan frekuensi. Penyebab perhitungan frekuensi tidak pernah sama adalah karena suku cadang piano seperti senar, bearing,

dilakukan oleh Erastosthenes adalah suatu hermeneutika visual. Don Ihde, Postphenomenology and Technoscience, p.65.

19 Seyyed Hossein Nasr, An Introduction to Islamic Cosmological Doctrines, p. 127.

20 Don Ihde, Technology and the Lifeworld, pp. 34-37. 
dan jarak hammer dengan senar. Materialitas suku cadang dan mekanika piano berpengaruh terhadap bagaimana suara dihasilkan. ${ }^{21}$ Selain itu praksis menyetem piano melalui persepsi pendengaran dan instrumen stem/tuning yang terkondisikan oleh voltase yang tidak stabil juga menentukan ketepatan frekuensi. Perlu diketahui perhitungan yang tidak pernah tepat ini berada pada wilayah detil yang dapat toleransi. Secara estetis tujuan dari tuning itu sendiri sebenarnya sudah tercapai. Mengacu pada dunia matematis yang tidak dapat diterapkan dengan tepat, maka kritik Husserl terhadap kecenderungan sains modern yang bersifat abstrak dan matematis dalam arti tertentu menjadi relevan. Perhitungan matematis adalah realitas yang berbeda dengan dunia sesungguhnya.

Mempertimbangkan hanya pengalaman dunia prakeilmuan, kita dihadapkan pada pengetahuan yang terbatas secara inderawi. Intensionalitas yang tertuju pada kompleksitas dunia inderawi pada dasarnya selalu tereduksi. Demikian pula pandangan dunia sains modern yang dikatakan berciri materialistis hanyalah mencipta suatu persepsi yang bersifat kultural atau makropersepsi. Dari problem persepsi ini, saya akan membahas hermeneutika instrumen. Istilah hermeneutika instrumen saya gunakan untuk menjelaskan moda pembacaan dalam ilmu melalui konstruksi dan mediasi-mediasi instrumental. Fakta tidak hanya merujuk pada fenomena yang diasumsikan terpisah dengan instrumen. Instrumen menjadi referensi dari materialitas ilmu yang tidak dapat dipersepsikan.

Hermeneutika instrumen dapat kita lihat pada penelitian sejarah ilmu dari Steven Shapin dan Simon Schaffer tentang eksperimen pompa udara Robert Boyle (1660)..$^{22}$ Boyle membuat pompa udara (pneumatic engine) untuk mencipta keadaan ruang hampa (vaccum) untuk memaha-

21 Keterangan tersebut saya dapatkan dari buku panduan teknis piano yang dikeluarkan oleh Nippon Gakki Co. Ltd., Piano Technology. (Yamaha Indonesia, 1978). Penulis bekerja sebagai teknisi dan stemmer piano.

22 Steven Shapin \& Simon Schaffer, Leviathan and the Air-Pump: Hobbes, Boyle and the Experimental Life (Princeton, NJ: Princeton University Press, 1985). 
mi secara paradigmatis hal yang berkaitan dengan fakta atau menguji pengetahuan dalam filsafat alam. Pompa udara secara teknis menghilangkan udara dalam ruang terbuat dari kaca (receiver) sehingga tercipta ruang hampa. Ia digunakan untuk membuktikan suatu pengetahuan alam. Eksperimen yang dilakukan Boyle dapat kita katakan mengacu pada pemikiran tentang udara sebagai "substansi" yang menentukan kehidupan.

Shapin dan Schaffer mengulas perdebatan antara Boyle dan Thomas Hobbes mengenai perlunya eksperimen dalam filsafat alam. Boyle mencoba mengonstruksi suatu keadaan ruang hampa untuk mengetahui secara mendasar sebab dan akibat yang ada pada alam. Hobbes menanggapi bahwa eksperimen pompa udara Boyle tidak memungkinkan dengan argumen alam terdiri dari sepenuhnya materi (plenism) dan juga konstruksi teknologis pompa udara yang mengalami kebocoran. Menurut Hobbes, filsafat alam tidak bisa direduksi pada eksperimen karena membuat pengetahuan terdomestikasi pada situasi tertentu. Hobbes berpijak pada pemikiran tentang pentingnya pengetahuan dalam konteks lebih luas atau kepublikan pengetahuan. ${ }^{23}$

Eksperimen Boyle tentang pompa udara menjadi relevan terutama dalam konteks pembacaan materialitas ilmu. Hobbes berpendapat eksperimen Boyle mengonstruksi fakta yang diketahui terbatas oleh orang-orang tertentu dalam penelitian atau tidak bersifat publik. Namun kritik Hobbes terhadap Boyle berfokus pada fenomena termediasi yang hanya bisa dibuktikan melalui instrumen. Karena terbatas berada dalam instrumen, tentulah ia tidak bisa menjadi publik. Shapin dan Schaffer mengatakan instrumen dapat dikategorikan sebagai fakta yang mengonstruksi ilmu. ${ }^{24}$ Selain instrumen, menurut mereka, fakta dihasilkan melalui tulisan hasil eksperimen atau inskripsi dan juga konvensi komunitas keilmuan yang terlibat eksperimen.

23 Steven Shapin \& Simon Schaffer, Leviathan and the Air-Pump, pp. 111-115.

24 Steven Shapin \& Simon Schaffer, Leviathan and the Air-Pump, p. 25. 
Mengenai instrumentasi yang mengonstruksi fakta, selain Shapin dan Schaffer, dapat kita lihat pemikiran Bruno Latour. Setiap teks keilmuan, menurut Latour, semata-mata menyertakan inskripsi-inskripsi terbatas dalam wujud visual (gambar, grafik, atau diagram) yang dihasilkan oleh perangkat-perangkat inskripsi (inscription devices), yang kemudian menjadi syarat rasionalitas ilmu. Menurutnya yang utama adalah pengetahuan terpahami dalam relasi-relasi perangkat inskripsi atau instrumen dan termasuk ilmuwan yang melakukan penelitian. ${ }^{25}$ Latour menjelaskan bahwa realitas keilmuan melampaui pembahasan tentang fenomena termediasi. Instrumen atau perangkat inskripsi melebihi fungsinya dalam menghadirkan fenomena. Ilmu terkonstruksi secara sosial.

Dalam Actor Network Theory, Latour memosisikan teknologi simetri dengan manusia. Manusia dapat menjadi bagian dari teknologi atau sebagai perangkat inskripsi itu sendiri. Hasil penilitian seorang ilmuwan yang digunakan sebagai inskripsi menjadikan diri ilmuwan itu sendiri sebagai instrumen. Tapi bila kita telaah, teori ini tidak menjelaskan kesadaran menubuh (existential body) yang selalu berada dalam perspektif. Pemikiran Latour jatuh pada apa yang Ihde istilahkan dengan epistemologi god-trick, ${ }^{26}$ yaitu suatu pengetahuan tanpa referensi tubuh eksistensial. Tubuh yang tersituasikan, yang menjadi ciri dalam pengetahuan pascafenomenologis, mendekonstruksi teori pengetahuan yang selalu mengandaikan posisi di luar dunia pengalaman. ${ }^{27}$

25 Bruno Latour, Science in Action: How to Follow Scientist and Engineers Through Society (Cambridge: Harvard University Press, 1987), pp. 67-70.

26 Don Ihde, Bodies in Technology (Minneapolis: University of Minnesota Press, 2002), p. 1.

27 Andrew Pickering, seorang sosiolog cum filsuf, mengkritik argumen Ihde tentang epistemologi god-trick. Menurut Pickering posisi tubuh dalam fenomenologi sebagaimana diajukan Ihde berada dalam maknanya yang tidak spesifik atau tidak mengacu pada fakta. Selain itu Ihde menjelaskan relevansi tubuh yang tersituasikan dan materialitas ilmu melalui sebuah metafora (camera obscura). Kritik terhadap epistemologi god-trick adalah bahwa ia dirumuskan dari perspektif epistemologi god-trick itu sendiri. Andrew Pickering, "Ontology Engines," in Postphenomenology: A Critical Companion to Ihde, ed. Evan Selinger (New York: State University of New York Press, 2006), pp. 213-217. 
Latour dengan teorinya menafikan posisi tubuh dalam relasinya dengan instrumen. Meski demikian, teori Latour dapat menjadi argumen tentang instrumen sebagai fakta. Ilmu yang terkonstruksi berdasarkan perangkat inskripsi tidak bisa direduksi dalam wujud visual dan diskursus teoritis tentang dunia termediasi. Materialitas instrumen menentukan atau menjadi syarat keutuhan dari ilmu. Mengenai hal ini Latour dan Steve Woolgar berargumen bahwa fakta terintegrasi dengan perangkat inskripsi. Mereka meminjam istilah Gaston Bachelard, "phenomenotechnique," untuk menjelaskan keutamaan materialitas ilmu dalam wujud teknologi. ${ }^{28}$ Namun, fakta dibahas tidak terbatas pada instrumen tertentu dan dunia yang dimediasikannya sebagaimana Ihde. Menurut Latour dan Woolgar, pembacaan fakta tidak hanya dengan mediasi melainkan juga dengan konstruksi. Mereka melihat ilmu meliputi relasi ontologis materialitas perangkat-perangkat inskripsi.

Dari pemikiran Shapin dan Schaffer serta Latour dan Woolgar, dapatlah kita pahami instrumen tak bisa kita abaikan eksistensinya dalam suatu konstruksi fakta. Realitas keilmuan dalam pemikiran mereka tidak terbatas pada fenomena termediasi atau inskripsi. Seperti juga tentunya Ihde mengatakan bahwa ilmu menubuh dengan teknologi. Namun Ihde tidak seperti pemikiran Latour dan Woolgar dan juga Shapin dan Schaffer yang berfokus hanya pada fakta. Mediasi instrumental mencipta dunia yang terbatas secara fenomenologis (teramplifikasi dan tereduksi). Karena itu selalu ada dunia yang dikatakan lebih utuh secara inderawi. Ihde mengatakan hal tersebut telah membawa pada suatu pemikiran bahwa pengetahuan ultima (ultimate knowledge) berada dalam wilayah yang tak dapat dipersepsikan. Meski konstruksi teknologis dapat ditingkatkan kualitasnya, demikian Ihde, pengetahuan ultima hanya bisa diketahui dengan pembacaan. ${ }^{29}$

28 Bruno Latour and Steve Woolgar, Laboratory Life: The Construction of Scientific Facts (Princeton, NJ: Princeton University Press ), p. 64.

29 Don Ihde, Technics and Praxis, p.38 
Keberadaan pengetahuan ultima seperti dijelaskan oleh Ihde dapat kita telaah melalui metafora camera obscura. Ihde mengkritik metafora camera obscura yang digunakan oleh Descartes untuk menjelaskan teori pengetahuannya. Menurut Descartes, ruang gelap yang memproyeksikan cahaya dapat dianalogikan dengan pikiran (res cogito), sedangkan proyeksi cahaya yang menampilkan dunia luar ruang sebagai dunia. Ihde berargumen Descartes menafikan ruang eksternal yang menjadi syarat pikiran memahami dunia sebagai proyeksi. Ihde mempertanyakan posisi Descartes ketika ia berteori tentang camera obscura. Tepat di sinilah pascafenomenologi Ihde mendapatkan pijakannya, pengetahuan tak lepas dari eksistensi tubuh yang tersituasikan. ${ }^{30}$

Dengan metafora camera obscura, kita dapat mengategorikan pengetahuan ultima yang tak dapat dipersepsikan sebagai ruang gelap. Keterbatasan kita dalam mempersepsikan dunia menjelaskan tentang dunia yang tidak diketahui. Inilah menjadi ciri pengetahuan fenomenologis, intensionalitas dan mediasi-mediasi instrumental adalah terbatas. Pengetahuan ultima tidak pernah dapat kita jangkau secara absolut. Konsekuensinya, meski subjek Cartesian melalui fenomenologi Merleau-Ponty dikatakan telah keluar dari ruang gelap sebagaimana diteorikan oleh Ihde, keberadaan dunia yang tidak dapat dipersepsikan menjelaskan tentang ruang gelap itu sendiri. Dapat kita nyatakan bahwa kita belum benar-benar keluar dari ruang gelap. Perbedaannya dalam konteks ultimate knowledge ini, ruang gelapnya bersifat eksternal sedangkan dalam filsafat Descartes bersifat internal.

Fakta dalam filsafat teknologi Ihde terpahami dalam "variasi fenomenologis instrumental." Fenomena diketahui dan menjadi fakta pertama-tama berdasarkan relasi-relasi manusia-instrumen-dunia. Tentang materialitas instrumen sebagai fakta dalam ilmu, kita bisa lihat pemikiran Ihde tentang kesatuan relasional mediasi-mediasi instrumental yang ia istilahkan dengan relasi-relasi transparansi, yaitu transparansi kemenubuhan (manusia-instrumen) dan transparansi hermeneutis (instrumen- 
dunia). ${ }^{31}$ Dalam transparansi kemenubuhan, instrumen menjadi ekstensi dari tubuh. Relasi tubuh-instrumen tidak disadari karena persepsi tertuju pada fenomena termediasi, sedangkan dalam transparansi hermeneutis, instrumen dan dunia yang dimediasikannya menjadi kesatuan relasional. Fenomena termediasi dipersepsikan melalui pembacaan.

Menurut Ihde, dalam relasi-relasi transparansi, terutama dalam relasi hermeneutis yang menjadi ciri khas mediasi-mediasi instrumental dalam sains kontemporer, kita temukan posisi enigmatis epistemologis. Relasi transparansi hermeneutis membentuk kesatuan instrumen-dunia yang secara relasional tidak diketahui. ${ }^{32}$ Posisi enigmatis ini menyatakan dunia yang hendak dituju hanya dapat diketahui dengan pembacaan, sedangkan relasi instrumen-dunia itu sendiri tidak disadari (unexperienced). Instrumen menjadi quasi-other dalam memediasikan dan mentransformasikan dunia. Relasi ini bersifat enigmatis karena kita tidak mengetahui batasan antara instrumen dan dunia yang dimediasikannya. Ketika membaca dunia melalui instrumen, kita tidak mengetahui keterhubungan instrumen-dunia karena persepsi inderawi tertuju terbatas pada teks yang merupakan referensi dari fenomena sesungguhnya. Radio telescope, misalnya, memediasikan materialitas benda langit dalam bentuk data gelombang frekuensi. Persepsi inderawi kita tertuju pada instrumen radio telescope yang menjadi referensi materialitas benda langit, sedangkan relasi teknis radio telescope dan benda langit tidak kita ketahui. Enigma dalam relasi hermeneutis ini adalah ketika dunia mewujud dalam bentuk angka yang dikondisikan oleh relasi teknis instrumendunia.

Posisi enigmatis dalam relasi transparansi ini menjadi argumen gagasan instrumen sebagai fakta dalam ilmu. Posisi enigmatis menjelaskan bahwa fakta terkonstruksi berdasarkan spesifikasi teknis instrumen atau konstruksi teknologisnya. Instrumen memiliki spesifikasi dan karakter teknis yang menentukan bentuk pengetahuan yang dimediasi-

31 Don Ihde, Technology and the Lifeworld, pp. 86-87

32 Don Ihde, Technics and Praxis, p.37. 
kannya. Mengenai spesifikasi teknis instrumen yang menjelaskan relasi transparansi ini kita bisa lihat instrumen glucometer. Glucometer menjadi referensi eksistensi zat gula darah yang diketahui melalui pembacaan. Glucometer membaca zat gula darah melalui proses elektrokimia. Darah pada probe dibaca oleh enzyme electrode yang berisi glucose oxidase. Materialitas gula darah terealisasi secara hermeneutis dalam bentuk teks melalui glucometer. Ada suatu proses teknis tertentu yang memungkinkan suatu zat yang tak dapat dipersepsikan dapat dibaca sebagai pengetahuan. Berdasarkan penjelasan tersebut dapat kita katakan bahwa materialitas ilmu adalah meliputi konstruksi teknologis instrumen.

Meskipun demikian, inherensi instrumen-dunia dalam relasi transparansi tidak lantas menjadikannya fenomena yang sama. Dalam diskursus filsafat ilmu, Ihde mengkritik Patrick Heelan filsuf ilmu yang berpendapat instrumen dan fenomena yang dimediasikannya adalah kesatuan fakta. Heelan, menurut Ihde, melihat instrumen tidak berdasarkan suatu fenomenologi instrumentasi yang menjelaskan adanya relasi kemenubuhan dan terutama relasi hermeneutis. Mengacu pada filsafat teknologi Ihde, yang dijelaskan oleh Heelan adalah relasi transparansi hermeneutis. Kritik Ihde terhadap Heelan dapat juga kita tujukan terhadap Latour dan Woolgar serta Shapin dan Schaffer. Bahwa intensionalitas dan mediasi-mediasi instrumental dalam relasi kemenubuhan dan hermeneutis adalah sesuatu yang mendasar dalam konstruksi fakta. Instrumentasi tentunya tidak begitu saja mengonstruksi pengetahuan. Dalam mempersepsikan dunia terdapat struktur intensional dalam bentuk relasi-relasi instrumental fenomenologis.

Dari argumen tentang relevansi relasi-relasi ontologis instrumen (atau perangkat inskripsi) dan fenomenologi instrumentasi, dapat kita simpulkan bahwa membaca materialitas ilmu tidak terbatas pada fenomena termediasi dan terutama ketika ia telah menjadi inskripsi dalam wujud visual. Realitas keilmuan meliputi rasionalitas instrumen yang terkonstruksi secara teknologis yang menjadi condition of possibility pembacaan dunia tak dapat dipersepsi secara inderawi. Membaca materialitas ilmu adalah selalu membaca materialitas teknologi. 


\section{REALISME FENOMENOLOGIS RUANGSIBER}

Pada bagian ini akan dibahas realisme fenomenologis ruangsiber dengan mengacu pada mediasi-mediasi instrumental dalam fenomenologi instrumentasi. Bila dalam hermeneutika instrumen, instrumen memediasikan dunia dan menjadi kesatuan relasional fenomenologis, dalam realisme fenomenologis ruangsiber, instrumen terintegrasi ke dalam ruangsiber melalui teknologi informasi. Instrumen dan dunia yang dimediasikannya terdomestikasi dalam ruang layar dalam bentuk hiperteks.

Don Ihde membuat istilah "realisme fenomenologis" berkenaan dengan dunia termediasi dan terkonstruksi oleh instrumen. ${ }^{33}$ Dengan realisme fenomenologis, fenomena teramplifikasi dan mewujud sebagai pengetahuan melalui instrumentasi. Ihde menjelaskan lebih jauh realisme ini dalam diskursus filsafat ilmu dengan istilah realisme instrumental di mana pencapaian pengetahuan selalu bermula dari praksis eksperimental dan instrumentasi. Berdasarkan realisme fenomenologis Ihde tersebut, saya mendefinisikan transformasi dunia termediasi yang melampaui partikularitas instrumen dengan realisme fenomenologis ruangsiber.

Infrastruktur ruangsiber meliputi teknologi informasi dan komunikasi yang membentuk konsep ruang dalam suatu jaringan. Teknologi internet mengoneksi komputer-komputer melalui server secara global. Ruangsiber menemukan bentuknya dalam ruang layar yang berisi data hiperteks (teks, audio, video, dan citra) atau hyperlink yang terkoneksi. Pada awalnya akses ruangsiber terbatas dalam bentuk teks (Email) dan audio (VoIP). Seiring dengan perkembangan teknologi komputer, ruangsiber mewujud dalam bentuk grafik komputer (citra 3D, animasi dan video) yang bersifat isomorfis dengan realitas sesungguhnya.

33 Don Ihde,Technics and Praxis, p. 49. 
Grafik komputer menjadi basis terbentuknya konsep ruang dalam sebuah medium. Dalam filsafat teknologi Ihde, konsep ruang dipahami berdasarkan multistabilitas persepsi. ${ }^{34}$ Multistabilitas dalam ruangsiber adalah tentang ragam bentuk persepsi visual ruang layar. Mengenai multistabilitas persepsi ini, Ihde mencontohkan kubus Necker. Kubus Necker menjelaskan tentang bagaimana suatu benda menghasilkan dua bentuk perspektif yang berbeda. Melalui multistabilitas persepsi, Ihde mengatakan sebuah grafik tidak hanya menampilkan dua bentuk perspektif yang berbeda. Citra, animasi dan tentunya grafik video dalam ruang layar dapat dipersepsikan ke dalam berbagai perspektif sehingga mencipta dunia atau virtualitas dalam ruang layar. ${ }^{35}$

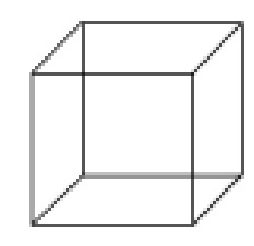

Multistabilitas ruangsiber, selain ragam bentuk persepsi ruang layar, dalam filsafat teknologi Ihde adalah pengalaman dunia inderawi yang tereduksi pada kualitas hiperteks. Dengan multistabilitas ini, kita mengakses ruangsiber sebagaimana dunia sesungguhnya dalam batas-batas ruang layar. Tidak hanya tubuh-tubuh yang terkoneksi, perkembangan teknologi komputer memungkinkan suatu instrumen terkoneksi dengan internet. Penggunaan instrumen dalam ruangsiber tidak terbatas pada partikularitasnya dalam relasi kemenubuhan atau relasi hermeneutis. Relasi manusia-instrumen berekstensi melampaui relasi yang bersifat partikular. Semua bentuk instrumen terdomestikasi dalam ruang layar.

Situs yang merepresentasikan multistabilitas ruangsiber adalah situs informasi cuaca seperti Accuweather (www.accuweather.com) dan BMKG (www.bmkg.go.id). Situs Accuweather menginformasikan secara

34 Don Ihde, Postphenomenology: Essays in the Postmodern Context, p. 70.

35 Don Ihde, Technology and the Lifeworld, p. 145. 
realtime cuaca, kecepatan angin dan kadar suhu secara global. Dunia yang berjarak diketahui melalui instrumen yang terkoneksi dengan internet. Dalam fenomenologi instrumentasi, dunia yang dihadirkan situs Accuweather ini tereduksi dalam relasi hermeneutis. Dalam relasi ini, kita mempersepsikan dunia sebagai sebuah teks. Fenomena cuaca suatu kota termediasikan melalui relasi hermeneutis dalam bentuk data hiperteks.

Situs BMKG lebih lengkap menginformasikan cuaca dengan menampilkan citra permukaan bumi, awan dan pergerakan awan. Satelit cuaca BMKG menggunakan teknologi inframerah untuk membaca suhu pada gumpalan awan. Sebagaimana tertulis dalam situs tersebut, warna putih yang dihasilkan oleh satelit adalah awan dengan kandungan uap air, sedangkan warna biru adalah awan dengan kelembaban tinggi yang berisi kristal-kristal es. Melalui teknologi inframerah, kualitas suhu pada awan dapat diidentifikasi dengan melihat warnanya. Citra satelit awan dalam fenomenologi instrumentasi merupakan variasi fenomenologis horisontal (horisontal instrumental variant). Citra yang dihasilkan mewujud dengan ciri tertentu yang merupakan suatu pengetahuan yang berbeda dengan citra yang dihasilkan tanpa teknologi inframerah.

Instrumen lainnya yang terintegrasi dengan ruangsiber dalam situs BMKG adalah stasiun seismik. Jaringan stasiun seismik BMKG tersebar di wilayah Nusantara. Stasiun ini mendeteksi gempa dan potensi tsunami. Instrumen pendeteksi gempa merepresentasikan fenomena yang terspesifikasi pada data teknis tertentu. Dengannya dipahami adanya variasi fenomenologis yang dimediasikan oleh instrumen kegempaan. Dalam variasi ini, seismograph menginformasikan fenomena gempa dan intensitasnya ke dalam ruangsiber. Gempa di lokasi tertentu diketahui dalam ruangsiber dalam ukuran magnitudonya, kedalaman gempa, dan lokasi tepat terjadinya gempa dalam garis sudut peta bumi. Informasi yang dihasilkan oleh instrumentasi seismik ini dalam fenomenologi instrumentasi merupakan variasi fenomenologis dalam kategori vertikal (vertical instrumental possibility). Dunia yang dimediasikan oleh instrumen mewujud dalam bentuk data. Tidak seperti teknologi inframerah pada 
satelit cuaca yang lebih mendekati realitas sesungguhnya yang merupakan variasi horisontal, dalam instrumentasi seismik, fenomena gempa tereduksi pada grafik frekuensi dan pada saat yang sama teramplifikasi.

Selain pembacaan melalui ruang layar seperti situs informasi cuaca, karakter non-netral dan multistabilitas ruangsiber memungkinkan untuk mengontrol secara langsung instrumen-instrumen yang berjarak dalam relasi hermeneutis dan relasi kemenubuhan. Bentuk kontrol ini dalam ruangsiber hanya dapat dimungkinkan dengan teknologi robotis. Setiap instrumen teknologis yang terkomputerisasi baik dalam hal kontrol on/ off dan yang utama kontrol gerak robotis dapat terintegrasi ke dalam ruangsiber. Tanpa teknologi robotis tidak dimungkinkan untuk mengontrol gerak dan operasionalnya dalam ruangsiber. Teknologi robotis menjadi syarat instrumen dapat dikontrol dalam ruangsiber.

Teleskop online adalah contoh teknologi robotis yang dapat diakses melalui teknologi internet. Teleskop dan fenomena visual yang ditampilkannya memiliki kualitas yang sama dalam wujud entitas informatif hiperteks. Dengan teleskop online (seperti misal www.slooh.com atau www.telescope.org), kita mengakses aktivitas teleskop robotis yang berjarak dalam relasi kemenubuhan. Relasi kemenubuhan ini tidak bersifat langsung, materialitas teleskop termediasikan oleh teknologi informasi. Partikularitas teleskop terdomestikasi dalam multistabilitas ruang layar, relasi manusia-instrumen dimediasikan oleh dua bentuk teknologi. Suatu instrumen yang terkoneksi dengan internet, yang berada di lokasi tertentu dan bersifat partikular sebagai keutuhan sebuah instrumen, dapat dikontrol tanpa relasi yang bersifat langsung. Diagramnya digambarkan sebagai berikut:

\section{Manusia $\longrightarrow$ Internet (Mediator I) $\longrightarrow$ Instrumen (Mediator II) $\longrightarrow$ Dunia}

Contoh teknologi robotis yang diakses melalui teknologi informasi dan komunikasi lainnya adalah robot Curiosity Rover yang dikirim ke planet Mars. Curiosity memiliki instrumen yang digunakan untuk meniliti planet Mars. Teknologi kamera (ChemCam) pada robot ini digunakan untuk navigasi, mengetahui geologi dan unsur kimia pada batu dan 
tanah permukaan Mars. ChemCam menggabungkan teknologi Laser Spectroscopy dan teleskop Remote Micro Imager. Selain sebagai instrumen keilmuan, kemampuan teknis robot ini menjelajah, mengebor, dan menyekop permukaan tanah dan bebatuan di Mars. Robot Curiosity menggunakan teknologi informasi dan komunikasi agar dapat dikontrol gerak robotisnya. Kontrol terhadap robot ini melalui gelombang radio yang dikirim dalam bentuk data secara khusus dari Bumi.

Dunia yang dimediasikan robot Curiosity merupakan variasi instrumental fenomenologis. Variasi ini tidak hanya pengetahuan yang hadir dalam ruang layar dalam relasi hermeneutis. Ia bersifat non-netral dalam arti instrumen robotis tersebut dapat dikontrol gerak robotisnya dengan teknologi informasi dan komunikasi. Curiosity memediasikan dunia yang eksistensinya dalam ranah instrumentasi. Dua bentuk dunia yang dihadirkan oleh Curiosity adalah fenomena visual gerak robotis dan fenomena keilmuan yang dimediasikan instrumen yang ada pada Curiosity. Meski robot ini terbatas dikontrol oleh para ilmuwan NASA, publisitas pengetahuannya dapat kita akses secara online dalam akun Twitternya MarsCuriosity dan secara khusus dalam situsnya www.mars.jpl.nasa.gov. Informasi kegiatan robot ini meliputi citra dan video yang berisi laporan terbaru hasil penelitian di planet Mars.

Setiap instrumen yang terkomputerisasi dapat terkoneksi ke dalam ruangsiber. Intensionalitas teknis instrumental ditransformasikan ke dalam bentuk hiperteks dan tereduksi dalam kualitas audio visual. Kualitas dunia inderawi yang bersifat kompleks yang dimediasikan instrumen dipersepsikan dalam batas-batas multistabilitas ruang layar. Relasi manusia, internet dan instrumen menciptakan sebuah variasi instrumental yang memunculkan istilah realisme fenomenologis ruangsiber.

\section{SIMPULAN}

Relevansi praksis dan instrumentasi telah membentuk perspektif baru dalam filsafat ilmu. Ilmu pengetahuan selalu berawal dari kesadaran menubuh dan termediasikan oleh teknologi. Intensionalitas dalam 
praksis keilmuan sampai pada fase ketika menjadi mungkin menggapai pengetahuan melalui mediator. Dalam mempersepsikan dunia melalui mediator ini kita ketahui adanya struktur kesadaran relasional manusiainstrumen, seperti telah dijelaskan dalam filsafat teknologi Ihde, relasirelasi ini adalah relasi kemenubuhan dan relasi hermeneutis. Kedua bentuk relasi ini berada dalam korelasi intensional manusia-dunia.

Dapat kita simpulkan bahwa pembacaan materialitas ilmu menjadi rasional terkonstruksi dan termediasi instrumen. Materialitas ilmu dipahami meliputi konstruksi teknologis dan mediasi-mediasi instrumental. Akhirnya mengenai intensionalitas dan mediasi-mediasi instrumental, moda ektensifikasi tidak hanya pada tubuh dalam relasinya dengan instrumen. Dengan teknologi internet, kita dapat mengontrolnya secara "elektronis." Dalam konteks ini ada dua bentuk mediator dalam menggapai pengetahuan. Materialitas pengetahuan, selain dalam bentuk artefak teknologi, berekstensi dalam bentuk hiperteks dalam ruangsiber yang dapat diakses secara publik melalui mediasi teknologi informasi.

Demikian pembahasan tentang teknologi dan materialitas ilmu berdasarkan fenomenologi instrumentasi Ihde. Penulis berpikir bahwa filsafat teknologi Ihde perlu dipertimbangkan untuk diketahui sebagai metode dalam ilmu-ilmu yang selalu mengandaikan penggunaan instrumen. Merefleksikan ilmu tanpa teknologi tentu akan menjadikan-nya tidak berpijak dan membumi. Inilah yang membuat filsafat teknologi memiliki kelebihan tersendiri dalam diskursus filsafat masa kini.

\section{DAFTAR RUJUKAN}

Díaz-Guardamino, Marta. "Rock Art and Digital Technologies: the Application of Reflectance Transformation Imaging (RTI) and 3D Laser Scanning to the Study of Late Bronze Age Iberian Stalae." Menga: Journal of Andalusian Prehistory 3:4 (2013). Diakses dari www.Academia.edu.

Dusek, Val. Philosophy of Technology: An Introduction. Blackwell Publishing. UK, 2005. 
Feenberg, Andrew. "The Mediation Is the Message: Rationality and Agency in the Critical Theory of Technology". Techné: Research in Philosophy and Technology. Vol. 17:1. Winter, 2013.

Husserl, Edmund. The Crisis of European Science and Trancendental Phenomenology. Transl. David Carr. Northwestern University Press, 1954.

. The Basic Problems of Phenomenology: From the Lectures, Winter Semester, 1910-1911. Translated by Ingo Farin and James G. Hart. Springer. Netherlands, 2006.

Heidegger, Martin. The Question Concerning Technology and Other Essays. Penerjemah: W. Lovitt. Harper and Row. New York, 1977.

. Being and Time. Diterjemahkan oleh John Macquarrie \& Edward Robinson. Oxford Basil Blackwell. Oxford, 1973.

Ihde, Don. Bodies in Technology, Electronic Mediations; V. 5. Minneapolis: University of Minnesota Press, 2002.

. Consequences of Phenomenology. State University of New York, 1986.

- Instrumental Realism: The Interface between Philosophy of Science and Philosophy of Technology. Bloomington and Indianapolis: Indiana University Press, 1991.

. Postphenomenology: Essays in the Postmodern Context. Evanston, IL: Northwestern University Press, 1993.

- Postphenomenology-Again? Working Paper from Centre of STS Studies No. 3. University of Aarhus, 2003.

. Postphenomenology and Technoscience: Peking University Lecture (SUNY Series of the Philosophy of the Social Sciences). New York: State University of New York Press, 2009.

. Science in Action: How to Follow Scientist and Engineers Through Society. Cambridge: Harvard University Press, 1987.

. Technic and Praxis. Holland and Boston: D Riedel Publishing Company, 1979.

. Technology and the Lifeworld: from Garden to Earth. Bloomington and Indianapolis: Indiana University Press, 1990.

\& Woolgar, Steve. Laboratory Life: The Construction of Scientific Facts. Princeton, NJ: Princeton University Press, 1986. 
Merleau-Ponty, Maurice. The Visible and the Invisible. Northwestern University Press, 1968.

. Phenomenology, Language and Sociology: Selected Essays of Merleau-Ponty. Heineman, London, 1974.

Nasr, Seyyed Hossein. An Introduction to Islamic Cosmological Doctrines: Conceptions of Nature and Methods Used for its Study by Ikhwan AlShafa, Al-Biruni, and Ibn Sina. Revised Edition. The Pitman Press, Great Britain, 1978.

Nippon Gakki Co., Ltd. Piano Technology. Yamaha Musik Indonesia, 1978.

Shapin, Steven \& Schaffer, Simon. Leviathan and the Air-Pump: Hobbes, Boyle and the Experimental Life. Princenton University Press, 1985.

Selinger, Evan (ed.). Postphenomenology: Critical Companion to Ihde. State University of New York Press, 2006.

Pickering, Andrew. “Ontology Engines." In Postphenomenology: Critical Companion to Ihde. Ed. Evan Selinger. New York: State University of New York Press, 2006. 